\section{Argemone mexicana: chemical and pharmacological aspects}

Revista Brasileira de Farmacognosia Brazilian Journal of Pharmacognosy

23(3): 559-575, May/Jun. 2013

\section{Goutam Brahmachari," Dilip Gorai, Rajiv Roy}

Laboratory of Natural Products \& Organic Synthesis, Department of Chemistry, Visva-Bharati University, West Bengal, India.

\begin{abstract}
The Papaveraceae, informally known as the poppy family, are an ethnopharmacologically important family of 44 genera and approximately 760 species of flowering plants. The present work offers a review addressing the detailed chemistry and pharmacology of Argemone mexicana L. regarded as one of the most significant plant species in traditional system of medicine. The plant is used in different parts of the world for the treatment of several ailments including tumors, warts, skin diseases, inflammations, rheumatism, jaundice, leprosy, microbial infections, and malaria. Interestingly, the plant is the source of a diverse kind of chemical constituents although alkaloids are mostly abundant. Beyond pharmaceutical efficacies, certain plant parts also show toxic effects as well. Hence, an up-to-date information on the chemical and pharmacological knowledge on this plant may be helpful to guide researchers anticipating to undertake further investigations in these directions. The present review covers literature up to 2012 and enlists 111 references.
\end{abstract}

Review

Received 16 Oct 2012

Accepted 6 Feb 2013

Available online 5 Mar 2013

Keywords:

Argemone mexicana biological activity

Papaveraceae

pharmaceutical potential phytochemical constituents traditional uses

ISSN $0102-695 \mathrm{X}$ DOI: $10.1590 / \mathrm{S} 0102-695 \times 2013005000021$

\section{Introduction}

Argemone mexicana L., known as Ghamoya (class: Magnoliopsida Dicotyledons; subclass: Magnoliidae; order: Papaverales; family: Papaveraceae; Figure 1) is an exotic weed indigenous in South America but has widespread distribution in many tropical and sub-tropical countries including West Africa (Ibrahim \& Ibrahim, 2009). This plant is common everywhere by roadsides and fields in India as well (Bhalke \& Gosavi, 2009). The plant is an erect prickly annual herb of about $1 \mathrm{~m}$ high; leaves are usually 5 to $11 \mathrm{~cm}$ long, and more or less blotched with green and white, glaucous broad at the base, half-clasping the stem prominently sinuate-lobed, and spiny (Chopra et al., 1956). The flowers become 4 to $5 \mathrm{~cm}$ in diameter, and are terminal, yellow, and scentless. The capsule is spiny, obovate or elliptic-oblong, and about $3 \mathrm{~cm}$ in length. The seeds are spherical, shining, black and pitted.

A. mexicana is considered as an important medicinal plant in India; the yellow juice, which exudes when the plant is injured, has long been used in India as traditional medicine for dropsy, jaundice, ophthalmia, scabies and cutaneous affections (Chopra et al., 1956; Ambasta, 1986; Sharma et al., 2012). Different parts of this plant are used in chronic skin diseases, and also as emetic, expectorant, demulcent and diuretic; the seeds and seed oil are employed as a remedy for dysentery, ulcers, asthma and other intestinal affections (Chopra et al., 1956; Bose et al., 1963; Ambasta, 1986; Prajapati et al., 2003; Savithramma et al., 2007). Leaves and seeds are also reported to find application in maintaining normal blood circulation and cholesterol level in human body (Albuquerque et al., 2007); these plant parts possess anti-venom property as well (Makhija \& Khamar, 2010; Minu et al., 2012). Flowers are found to be expectorant and have been used in the treatment of coughs (Brahmachari et al., 2010). In Brazil, the plant is commonly known as 'cardo-santo' and used traditionally in the treatment of a number of diseases (Agra et al., 2007; 2008; Bieski et al., 2012). Seeds of the plant are used as purgative, laxative and digestive while its latex is used against conjunctivitis (Agra et al., 2008). Besides, its infusion finds application against hypertension in Brazil (Bieski et al., 2012). The present review deals with the phytochemical and pharmacological aspects of $A$. mexicana covering the literature up to 2012.

\section{Material and Methods}

The chemical constituents isolated and identified from Argemone mexicana, pharmacological activities exhibited by the isolated compounds as well as by the crude plant extracts were searched across the Medline (National Library of Medicine) and ScienceDirect databases. The data were updated in January 2013, using the search-terms Argemone mexicana, chemical constituents, biological activities, pharmacological activities or properties of Argemone mexicana as keywords. In addition, the reference lists of all papers identified were reviewed. 


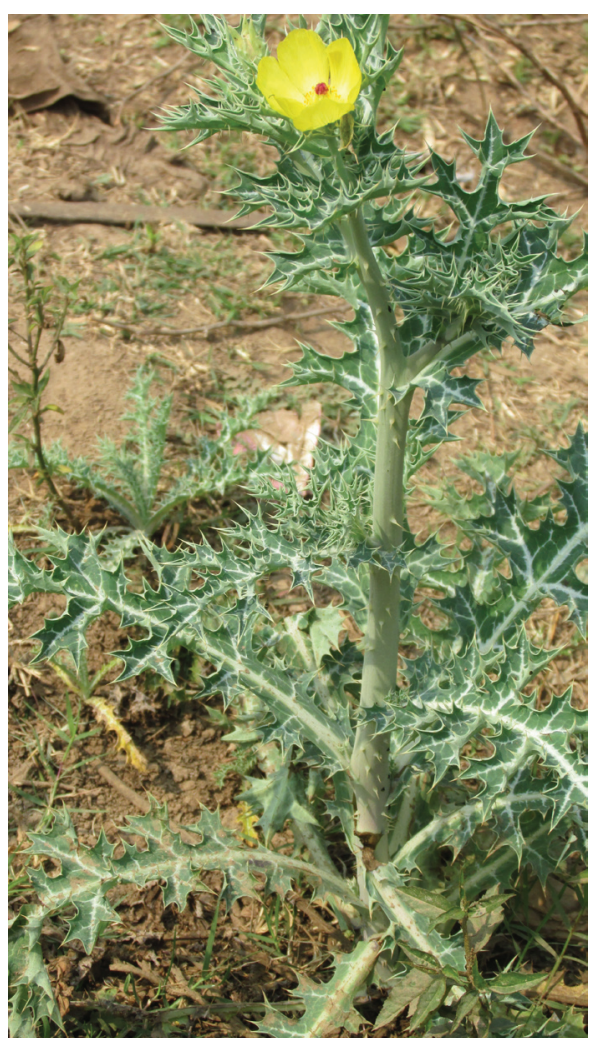

Figure 1. Argemone mexicana L., Papaveraceae.

\section{Chemical constituents}

Chemical constituents isolated so far from this plant are presented in Table 1. Most of the isolated compounds belong to the class of alkaloids; besides, terpenoids, flavonoids, phenolics, long-chain aliphatic compounds, and few aromatic compounds are found to be other constituents of this plant.

\section{Biological activities exhibited by the plant and plant constituents}

Various biological activities exhibited by both the crude plant extracts and isolated chemical constituents are described categorically under the following sub-sections:

\section{Antibacterial activity}

Crude plant extracts of $A$. mexicana L. as well as some of its chemical constituents were found to exhibit antimicrobial potential (Saranya et al., 2012). Rahman and his group (2009) studied in vitro antibacterial activity of the crude stems extracts ( $n$-hexane, chloroform, ethyl acetate and ethanol) of the plant against a number of food-borne gram positive and gram negative bacteria such as Bacillus subtilis,
Staphylococcus aureus, Listeria monocytogenes, Clostridium botulinum, Clostridium perfringens, Escherichia coli, Pseudomonas aeruginosa and Salmonella typhimurium. The organic crude extracts showed potent antibacterial activity against the bacterial strains at a concentration of $10 \mu \mathrm{L}$ exhibiting zones of inhibition in the range of 10.1 to $21.4 \mathrm{~mm}$ with MIC values ranging from $62.5-500 \mu \mathrm{g} / \mathrm{mL}$ (Rahman et al., 2009). This study indicates the presence of some antibacterial chemical constituents in the plant, which might find useful applications. It was also reported that chloroform extract of $A$. mexicana seeds at a dose of 500 $\mathrm{mg} / \mathrm{mL}$ show significant antimicrobial activity against both gram positive and gram negative microorganisms such as E. coli, P. aeroginosa, Enterococcus sp., Salmonella typhi, S. aureus with MIC values in the range of $2-5 \mathrm{mg} / \mathrm{mL}$ (Singh et al., 2009b); however, the methanol extract at the same dose showed a moderate activity only against $P$. aeruginosa, $S$. typhi and $S$. aureus. In addition, the $50 \%$ aqueous methanolic extract of A. mexicana fruits was tested for its antibacterial potential against some gram positive and gram negative bacteria such as Klebsiella oxytoca, Vibrio damsella, Enterobactor aerogens and E. coli, and it was revealed that the crude extract is more effective against gram negative bacteria as tested (Jain et al., 2012). Pandey \& Karanwal (2011) also demonstrated that the ethanolic extract of the seeds possesses significant antibacterial activity against the pathogenic bacteria, $P$. aeruginosa, E. coli and $S$. aureus with MIC value $230 \mu \mathrm{g} / \mathrm{L}$. Similar kind of studies on antibacterial efficacy of different organic and aqueous plant extracts were also investigated (Bhattacharjee et al., 2006; Abubacker \& Ramanathan, 2012; Bhardwaj et al., 2012). Both ethanolic and aqueous extracts of $A$. mexicana were found to have antibacterial potential against Streptococcus mutans and Porphyromonas gingivalis responsible for oral cavity infection; the alcoholic extract showed greater potency against $S$. mutans with MIC value of $125 \mu \mathrm{g} /$ $\mathrm{mL}$, while the aqueous extract against $P$. gingivalis with MIC value of $78 \mu \mathrm{g} / \mathrm{mL}$ (Rosas-Pinon et al., 2012).

Different leaf extracts (acetone, methanol, ethanol and aqueous) of A. mexicana were found to exhibit antipseudomonal activity against multidrug resistant $P$. aeruginosa isolated from clinical samples (Sahu et al., 2012). Twenty-seven strains have been used for this antimicrobial study and applying agar well diffusion method, the MIC and minimum bactericidal concentration (MBC) values noted for acetone, methanol and ethanol are $10,8,8 \mathrm{mg} / \mathrm{mL}$ and $32,28,24 \mathrm{mg} / \mathrm{mL}$, respectively, thereby demanding that leaf of $A$. mexicana as complementary medicine in treating diseases caused by multidrug resistant strains of $P$. aeruginosa. Following the same procedure, another research group (Alagesaboopathi \& Kalaiselvi, 
Table 1. Chemical constituents of Argemone mexicana.

\begin{tabular}{|c|c|c|}
\hline Compound & Plant parts & Reference \\
\hline & & Alkaloids \\
\hline isocorydine (1) & apigeal parts & Israilov et al., 1986 \\
\hline berberine (2) & apigeal parts, seeds & $\begin{array}{l}\text { Israilov et al., 1986; Ito et al., 1990; Chang et al., 2003b; Haisova \& Slavik, } \\
\text { 1975; Fletcher et al., } 1993\end{array}$ \\
\hline dehydrocheilanthifoline (3) & whole plants & Chang et al., 2003b \\
\hline dehydrocorydalmine (4) & whole plants & Singh et al., 2010c; Singh et al., 2009a \\
\hline jatrorrhizine (5) & whole plants & Singh et al., $2010 \mathrm{c}$ \\
\hline columbamine $(\mathbf{6})$ & whole plants & Singh et al., 2010c \\
\hline coptisine (7) & whole plants & Chang et al., 2003b; Ito et al., 1990 \\
\hline$(+)$-reticuline $(\mathbf{8})$ & apigeal parts, aerial parts & $\begin{array}{l}\text { Israilov et al., 1986; Hussain et al., 1983; Chang et al., 2003a; Rahman, } \\
1994\end{array}$ \\
\hline protopine $(\mathbf{9})$ & apigeal parts, seeds & $\begin{array}{l}\text { Israilov et al., 1986; Ito et al., 1990; Chang et al., 2003b; Haisova \& Slavik, } \\
\text { 1975; Tripathi et al., } 1999\end{array}$ \\
\hline allocryptopine (10) & apigeal parts & Israilov et al., 1986; Chang et al., 2003b; Haisova \& Slavik, 1975. \\
\hline cryptopine (11) & whole plants & Haisova \& Slavik, 1975; Shamma, 1972 \\
\hline muramine (12) & whole plants & Nakkady et al., 1988 \\
\hline argemexicaine $\mathrm{A}(\mathbf{1 3})$ & whole plants & Chang et al., 2003b \\
\hline argemexicaine B (14) & whole plants & Chang et al., 2003b \\
\hline protomexicine (15) & aerial parts & Singh et al., 2012 \\
\hline 13-oxoprotopine (16) & aerial parts & Singh et al., 2012 \\
\hline 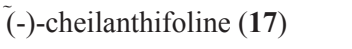 & apigeal parts & Israilov et al., 1986; Haisova \& Slavik, 1975; Shamma, 1972 \\
\hline$\tilde{(-)}$-scoulerine (18) & apigeal parts & Israilov et al., 1986; Haisova \& Slavik, 1975; Shamma,1972 \\
\hline$(+)$-cheilanthifoline $(\mathbf{1 9})$ & whole plants & Tripathi et al., 1999 \\
\hline (-)-stylopine (20) & Whole plants & Haisova \& Slavik, 1975; Shamma, 1972 \\
\hline nor-sanguinarine (21) & whole plants & Haisova \& Slavik, 1975; Tripathi et al., 1999; Rahman, 1994 \\
\hline chelerythrine (22) & whole plants & Chang et al., 2003b \\
\hline sanguinarine (23) & seeds & Chang et al., 2003b; Haisova \& Slavik, 1975; Fletcher et al., 1993. \\
\hline oxyhydrastinine (24) & whole plants & Hussain et al., 1983; Rahman, 1994; Nakkady et al., 1988 \\
\hline thalifoline (25) & whole plants & Nakkady et al., 1988 \\
\hline argemexirine (26) & whole plants & Singh et al., $2010 \mathrm{~b}$ \\
\hline$(+)$-argenaxine $(\mathbf{2 7})$ & aerial parts & Chang et al., 2003a \\
\hline (+)-higenamine (28) & aerial parts & Chang et al., 2003a \\
\hline$( \pm)$-tetrahydrocoptisine $(\mathbf{2 9})$ & whole plants & Singh et al., $2010 \mathrm{~b}$ \\
\hline (-)-tetrahydroberberine (30) & whole plants & Chang et al., 2003b \\
\hline dihydrocoptisine (31) & whole plant & Singh et al., $2010 \mathrm{~b}$ \\
\hline oxyberberine (32) & whole plants & Singh et al., 2010c; Singh et al., 2009a \\
\hline $\begin{array}{l}N \text {-demethyloxysanguinarine } \\
\text { (33) }\end{array}$ & aerial parts & Chang et al., 2003a \\
\hline pancorine (34) & aerial parts & Chang et al., 2003a \\
\hline$O$-methylzanthoxyline (35) & whole plants & Chang et al., 2003b \\
\hline nor-chelerythrine (36) & whole plants & Haisova \& Slavik, 1975 \\
\hline arnottianamide (37) & whole plants & Chang et al., 2003b \\
\hline $\begin{array}{l}( \pm) \text {-6-acetonyl } \\
\text { dihydrochelerythrine }(\mathbf{3 8})\end{array}$ & whole plants & Chang et al., 2003b; Nakkady et al., 1988; Migahid, 1978 \\
\hline dihydrosanguiranine (39) & seeds & Fletcher et al., 1993; Chang et al., 2003a \\
\hline dihydrochelerythrine (40) & tissues & Chang et al., 2003a \\
\hline angoline (41) & whole plants & Chang et al., 2003b; Chang et al., 2003a \\
\hline
\end{tabular}


8-acetonyl

dihydrosanguiranine (42)

8-methoxy

dihydrosanguiranine (43)

dihydropalmatine hydroxide (44)

(-)-argemonine (45) whole plants

aerial parts

seeds

plant resins
Nakkady et al., 1988

Singh et al., 2012

Ito et al., 1990

Rahman, 1994; Shamma, 1972<smiles>COc1cc2c3c(c1O)-c1c(ccc(OC)c1OC)CC3N(C)CC2</smiles>

1<smiles>[R]c1cc2c(c([R])c1[R2])C(=O)Cc1c([R])c([R6])c([R5])c([R4])c1CN(C)CC2</smiles>

$2 \mathrm{R}_{1}=\mathrm{R}_{2}=-\mathrm{OCH}_{2} \mathrm{O}-; \mathrm{R}_{3}=\mathrm{R}_{4}=\mathrm{OCH}_{3}$

$3 \mathrm{R}_{1}=\mathrm{OCH}_{3} ; \mathrm{R}_{2}=\mathrm{OH} ; \mathrm{R}_{3}=\mathrm{R}_{4}=-\mathrm{OCH}_{2} \mathrm{O}$ -

$4 \mathrm{R}_{1}=\mathrm{R}_{2}=\mathrm{R}_{3}=\mathrm{OCH}_{3} ; \mathrm{R}_{4}=\mathrm{OH}$

$5 \mathrm{R}_{1}=\mathrm{OH} ; \mathrm{R}_{2}=\mathrm{R}_{3}=\mathrm{R}_{4}=\mathrm{OCH}_{3}$

$6 \mathrm{R}_{1}=\mathrm{R}_{3}=\mathrm{R}_{4}=\mathrm{OCH}_{3} ; \mathrm{R}_{2}=\mathrm{OH}$

$7 \mathrm{R}_{1}=\mathrm{R}_{2}=\mathrm{R}_{3}=\mathrm{R}_{4}=-\mathrm{OCH}_{2} \mathrm{O}$ -

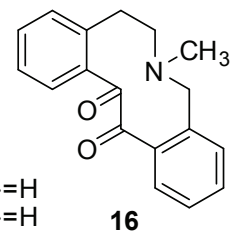

16

$18 \mathrm{R}_{1}=\mathrm{R}_{4}=\mathrm{OH} ; \mathrm{R}_{2}=\mathrm{R}_{5}=\mathrm{OCH}_{3} ; \mathrm{R}_{3}=\mathrm{H}(\beta)$

$19 \mathrm{R}_{1}=\mathrm{R}_{2}=-\mathrm{OCH}_{2} \mathrm{O}-; \mathrm{R}_{3}=\mathrm{H}(\alpha) ; \mathrm{R}_{4}=\mathrm{OH} ; \mathrm{R}_{5}=\mathrm{OCH}_{3}$

$20 \mathrm{R}_{1}=\mathrm{R}_{2}=\mathrm{R}_{4}=\mathrm{R}_{5}=-\mathrm{OCH}_{2} \mathrm{O}-; \mathrm{R}_{3}=\mathrm{H}(\alpha)$

$11 \mathrm{R}_{1}=\mathrm{R}_{2}=\mathrm{OCH}_{3} ; \mathrm{R}_{4}=\mathrm{R}_{5}=-\mathrm{OCH}_{2} \mathrm{O}-; \mathrm{R}_{3}=\mathrm{R}_{6}=\mathrm{R}_{7}=\mathrm{H}$

$12 \mathrm{R}_{1}=\mathrm{R}_{2}=\mathrm{R}_{4}=\mathrm{R}_{5}=\mathrm{OCH}_{3} ; \mathrm{R}_{3}=\mathrm{R}_{6}=\mathrm{R}_{7}=\mathrm{H}$

$13 \mathrm{R}_{1}=\mathrm{R}_{2}=-\mathrm{OCH}_{2} \mathrm{O}-; \mathrm{R}_{3}=\mathrm{R}_{4}=\mathrm{R}_{5}=\mathrm{H} ; \mathrm{R}_{6}=\mathrm{R}_{7}=\mathrm{OCH}_{3}$

$14 \mathrm{R}_{1}=\mathrm{R}_{4}=\mathrm{R}_{7}=\mathrm{H} ; \mathrm{R}_{2}=\mathrm{R}_{3}=\mathrm{OCH}_{3} ; \mathrm{R}_{5}=\mathrm{R}_{6}=-\mathrm{OCH}_{2} \mathrm{O}-$

$15 \mathrm{R}_{1}=\mathrm{R}_{2}=-\mathrm{OCH}_{2} \mathrm{O}-; \mathrm{R}_{3}=\mathrm{R}_{4}=\mathrm{R}_{5}=\mathrm{H} ; \mathrm{R}_{6}=\mathrm{OH} ; \mathrm{R}_{7}=\mathrm{OCH}_{3}$<smiles>c1cc2c(ccc3c4ccc5c(c4ncc23)OCO5)c2c1OCO2</smiles>

21<smiles>[R2]c1ccc2c3c([n+](C)cc2c1[R])-c1cc2c(cc1CC3)OCO2</smiles>

$22 \mathrm{R}_{1}=\mathrm{R}_{2}=\mathrm{OCH}_{3}$ $23 \mathrm{R}_{1}=\mathrm{R}_{2}=-\mathrm{OCH}_{2} \mathrm{O}-$<smiles>[R]c1cc2c(cc1[R])C(=O)N(C)CC2</smiles>

$24 \mathrm{R}_{1}=\mathrm{R}_{2}=-\mathrm{OCH}_{2} \mathrm{O}-$<smiles>[R]c1cc2c(cc1[R])[C@H](Cc1ccc([R6])c([R4])c1[R3])NCC2</smiles>

$26 \mathrm{R}_{1}=\mathrm{R}_{2}=\mathrm{OH} ; \mathrm{R}_{3}=\mathrm{R}_{4}=\mathrm{R}_{5}=\mathrm{H}$

$27 \mathrm{R}_{1}=\mathrm{R}_{2}=-\mathrm{OCH}_{2} \mathrm{O}-; \mathrm{R}_{3}=\mathrm{CH}_{2} \mathrm{OH} ; \mathrm{R}_{4}=\mathrm{R}_{5}=\mathrm{OCH}_{3}$ $28 \mathrm{R}_{1}=\mathrm{R}_{2}=\mathrm{R}_{5}=\mathrm{OH} ; \mathrm{R}_{3}=\mathrm{R}_{4}=\mathrm{H}$<smiles>[R2]c1ccc2c(c1[R])CN1CCc3cc4c(cc3C1C2)OCO4</smiles>

$29 \mathrm{R}_{1}=\mathrm{R}_{2}=-\mathrm{OCH}_{2} \mathrm{O}-$ $30 \mathrm{R}_{1}=\mathrm{R}_{2}=\mathrm{OCH}_{3}$<smiles>[R3]c1ccc2c(c1[R])C([R])N1CCc3cc4c(cc3C1C2)OCO4</smiles>

$31 \mathrm{R}_{1}=\mathrm{H} ; \mathrm{R}_{2}=\mathrm{R}_{3}=-\mathrm{OCH}_{2} \mathrm{O}$ -

$32 \mathrm{R}_{1}==\mathrm{O} ; \mathrm{R}_{2}=\mathrm{R}_{3}=\mathrm{OCH}_{3}$ 
<smiles>O=c1[nH]c2c3cc4c(cc3ccc2c2ccc3c(c12)OCO3)OCO4</smiles>

33<smiles>[R]c1c([R])c([R])c2c([R])c([R])c([R])c([R])c2c1[R]</smiles>

$34 \mathrm{R}_{1}=\mathrm{OCH}_{3} ; \mathrm{R}_{2}=\mathrm{R}_{3}=-\mathrm{OCH}_{2} \mathrm{O}-; \mathrm{R}_{4}=\mathrm{R}_{5}=\mathrm{H}$

$35 \mathrm{R}_{1}=\mathrm{R}_{2}=\mathrm{R}_{3}=\mathrm{H} ; \mathrm{R}_{4}=\mathrm{R}_{5}=\mathrm{OCH}_{3}$

$36 \mathrm{R}_{1}=\mathrm{R}_{4}=\mathrm{R}_{5}=\mathrm{H} ; \mathrm{R}_{2}=\mathrm{R}_{3}=\mathrm{OCH}_{3}$<smiles>[R3]C1=CC=C2OCOc3ccc4c(c3)N(C)C([R1])C(=C1[R2])C2=C4</smiles>

$38 \mathrm{R}_{1}=\mathrm{CH}_{2} \mathrm{COCH}_{3} ; \mathrm{R}_{2}=\mathrm{R}_{3}=\mathrm{OCH}_{3}$

$39 \mathrm{R}_{1}=\mathrm{H} ; \mathrm{R}_{2}=\mathrm{R}_{3}=-\mathrm{OCH}_{2} \mathrm{O}-$

$40 \mathrm{R}_{1}=\mathrm{H} ; \mathrm{R}_{2}=\mathrm{R}_{3}=\mathrm{OCH}_{3}$

$41 \mathrm{R}_{1}=\mathrm{R}_{2}=\mathrm{R}_{3}=\mathrm{OCH}_{3}$

$42 \mathrm{R}_{1}=\mathrm{CH}_{2} \mathrm{COCH}_{3} ; \mathrm{R}_{2}=\mathrm{R}_{3}=-\mathrm{OCH}_{2} \mathrm{O}-$

$43 \mathrm{R}_{1}=\mathrm{OCH}_{3} ; \mathrm{R}_{2}=\mathrm{R}_{3}=-\mathrm{OCH}_{2} \mathrm{O}-$<smiles>COc1cc2c(cc1OC)C1=[N+]([O-])CCc3ccc(OC)c(OC)c3C1C2</smiles>

44<smiles>COc1ccc(-c2ccc3cc4c(cc3c2NCO)OCO4)c(O)c1OC</smiles>

37<smiles>COc1cc2c(cc1OC)[C@@H]1Cc3cc(OC)c(OC)cc3[C@@H](C2)N1C</smiles>

45

\begin{tabular}{lll}
\hline trans-phytol (46) & aerial parts & Terpen \\
$\beta$-amyrin (47) & leaves & Shang et \\
\hline
\end{tabular}

46

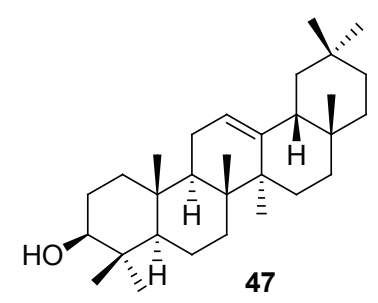

47

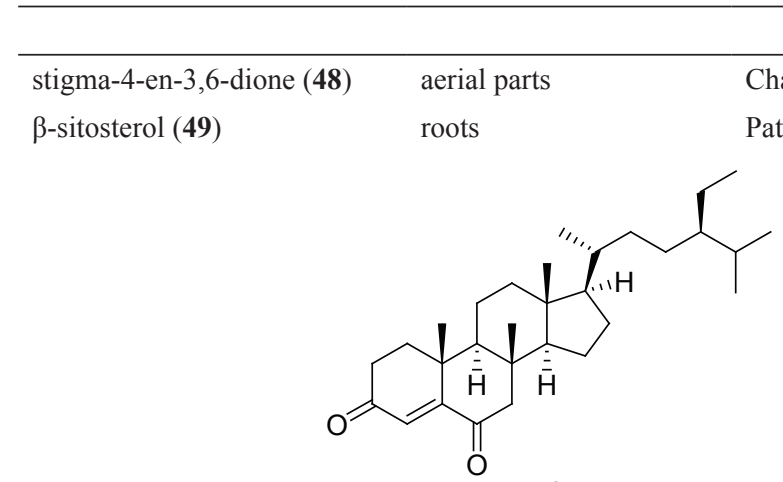

48

\section{Steroids}

Chang et al., 2003a

Pathak et al., 1985

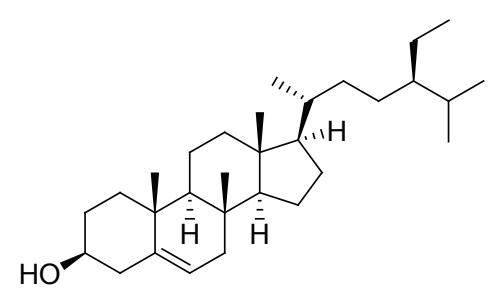

49

Carbohydrates

Sarraf et al., 1994

Sarraf et al., 1994

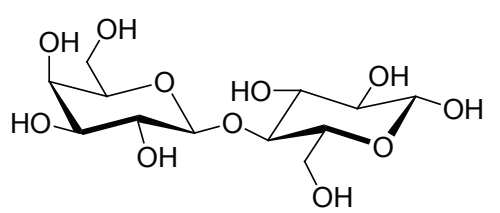

50

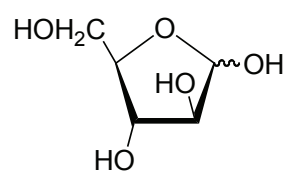

51 


\begin{tabular}{|c|c|c|c|}
\hline \multicolumn{4}{|c|}{ Long-chain alcohols } \\
\hline triacotan-11-ol (52) & aerial parts & \multicolumn{2}{|c|}{ Sangwan \& Malik, 1998} \\
\hline $\begin{array}{l}\text { triacotan-6, 11-diol (53) } \\
\text { (mexicanol) }\end{array}$ & aerial parts & \multicolumn{2}{|c|}{ Sangwan \& Malik, 1998; Dinda \& Banerjee, 1987} \\
\hline hentriacontane-3,20-diol (54) & flowers & \multicolumn{2}{|c|}{ Brahmachari et al., 2010} \\
\hline 11-oxo octacosanoic acid (55) & seeds & \multicolumn{2}{|c|}{ Rahman \& Ilyas, 1962; Gunstone et al., 1977} \\
\hline 11-oxo triacontanoic acid (56) & seeds & \multicolumn{2}{|c|}{ Fletcher et al., 1993; Gunstone et al., 1977} \\
\hline 9-oxo octacosanoic acid (57) & seeds & \multicolumn{2}{|l|}{ Gunstone et al., 1977} \\
\hline $\begin{array}{l}\text { (+)-6-hydroxy-6-methyl- } \\
\text { 9-oxo-octacosanoic acid } \\
\text { (argemonic acid) (58) }\end{array}$ & oil & \multicolumn{2}{|l|}{ Rukmini, 1975} \\
\hline $\begin{array}{l}\text { myristic acid (tetradecanoic } \\
\text { acid) (59) }\end{array}$ & oil & \multicolumn{2}{|c|}{ Badami \& Gunstone, 1962} \\
\hline palmitic acid (60) & oil & \multicolumn{2}{|c|}{ Badami \& Gunstone, 1962} \\
\hline stearic acid $(\mathbf{6 1})$ & oil & \multicolumn{2}{|c|}{ Badami \& Gunstone, 1962} \\
\hline arachidic acid (62) & oil & \multicolumn{2}{|c|}{ Badami \& Gunstone, 1962} \\
\hline oleic acid (63) & oil & \multicolumn{2}{|c|}{ Badami \& Gunstone, 1962} \\
\hline linoleic acid (64) & oil & \multicolumn{2}{|c|}{ Badami \& Gunstone, 1962} \\
\hline mexicanic acid (65) & aerial parts & \multicolumn{2}{|c|}{ Dinda \& Banerjee, 1987} \\
\hline \multicolumn{2}{|c|}{$\mathrm{CH}_{3}\left(\mathrm{CH}_{2}\right)_{n} \mathrm{CH}_{3}$} & \multicolumn{2}{|c|}{$\mathrm{CH}_{3}\left(\mathrm{CH}_{2}\right)_{\mathrm{n}} \mathrm{CO}_{2} \mathrm{H}$} \\
\hline \multicolumn{2}{|c|}{$\begin{array}{l}\mathbf{5 2} n=28(11-\text { ol }) \\
53 n=30 \text { (6,11-diol) } \\
\mathbf{5 4} n=29 \text { (3,20-diol) }\end{array}$} & $\begin{array}{l}\mathbf{5 5} \mathrm{n}=26 \text { (11-one) } \\
\mathbf{5 6} \mathrm{n}=28 \text { (11-one) } \\
\mathbf{5 7} \mathrm{n}=26 \text { (9-one) } \\
\mathbf{5 8} \mathrm{n}=26\left(6-\mathrm{CH}_{3} ; 6-\mathrm{OH} ; 9 \text {-one) }\right. \\
\mathbf{5 9} \mathrm{n}=12 \\
\mathbf{6 0} \mathrm{n}=14\end{array}$ & $\begin{array}{l}\mathbf{6 1} n=16 \\
\mathbf{6 2} n=18 \\
\mathbf{6 3} n=16 \text { (9-ene) } \\
\mathbf{6 4} n=16 \text { (9,12-diene) } \\
\mathbf{6 5} n=15 \text { [4-ene(Z); 10-OH) }\end{array}$ \\
\hline
\end{tabular}

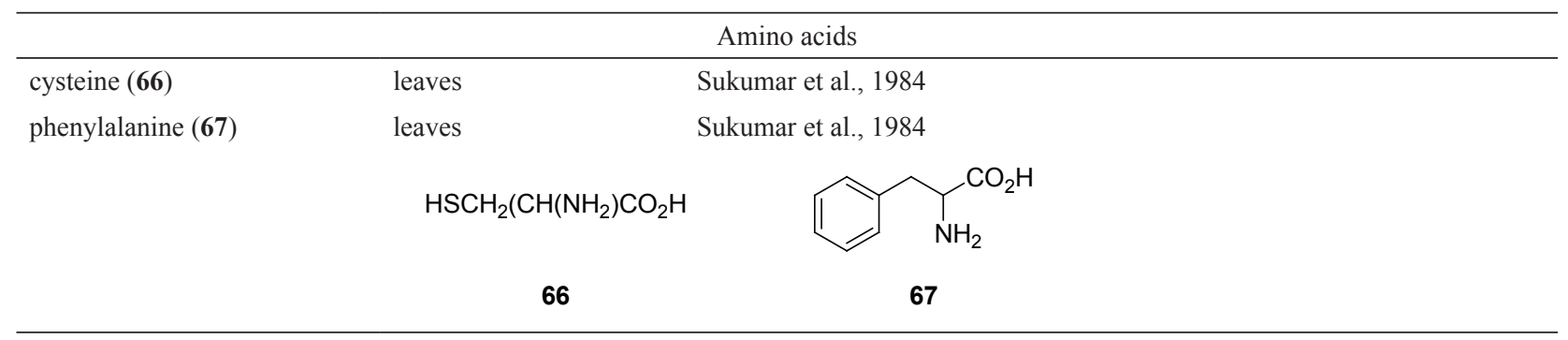

\begin{tabular}{|c|c|c|}
\hline \multicolumn{3}{|r|}{ Flavonoids } \\
\hline luteolin (68) & seeds & Harborne \& Williams, 1983 \\
\hline eriodictyol (69) & seeds & Harborne \& Williams, 1983 \\
\hline $\begin{array}{l}\text { isorhamnetin-3-O- } \beta \text {-D- } \\
\text { glucopyanoside (70) }\end{array}$ & leaves, flowers & $\begin{array}{l}\text { Chang et al., 2003a; Sukumar et al., 1984; Rahman \& Ilyas, 1962; } \\
\text { Krishnamurthi et al., 1965; Anthal et al., } 2012\end{array}$ \\
\hline isorhamnetin (71) & flowers & Pathak et al., 1985; Rahman \& Ilyas, 1962 \\
\hline $\begin{array}{l}\text { isorhamnetin-7-O- } \beta-\mathrm{D}- \\
\text { diglucopyanoside (72) }\end{array}$ & flowers & Rahman \& Ilyas, 1962 \\
\hline $\begin{array}{l}\text { isorhamnetin-3,7- } O-\beta-\mathrm{D}- \\
\text { diglucopyanoside (73) }\end{array}$ & flowers & Krishnamurthi et al., 1965 \\
\hline quercetin (74) & whole plants & Singh et al., 2011 \\
\hline quercetrin (75) & aerial parts & Singh et al., 2012 \\
\hline rutin $(76)$ & whole plants, aerial parts & Singh et al., 2011; Singh et al., 2012 \\
\hline mexitin (77) & aerial parts & Singh et al., 2012 \\
\hline
\end{tabular}


<smiles>[R6]Oc1cc(O)c2c(=O)c([R])c(-c3ccc(O)c([R9])c3)oc2c1</smiles>

$68 \mathrm{R}_{1}=\mathrm{R}_{2}=\mathrm{H} ; \mathrm{R}_{3}=\mathrm{OH}$

$70 \mathrm{R}_{1}=\mathrm{OGIc} ; \mathrm{R}_{2}=\mathrm{R}_{3}=\mathrm{H}$

$71 \mathrm{R}_{1}=\mathrm{OCH}_{3} ; \mathrm{R}_{2}=\mathrm{H} ; \mathrm{R}_{3}=\mathrm{OH}$

$72 \mathrm{R}_{1}=\mathrm{OH} ; \mathrm{R}_{2}=$ di-Glc; $\mathrm{R}_{3}=\mathrm{H}$

$73 \mathrm{R}_{1}=\mathrm{OGlc} ; \mathrm{R}_{2}=\mathrm{Glc} ; \mathrm{R}_{3}=\mathrm{H}$

$74 \mathrm{R}_{1}=\mathrm{R}_{3}=\mathrm{OH} ; \mathrm{R}_{2}=\mathrm{H}$

$75 \mathrm{R}_{1}=\mathrm{ORha} ; \mathrm{R}_{2}=\mathrm{H} ; \mathrm{R}_{3}=\mathrm{OH}$

$76 \mathrm{R}_{1}=$ ORut; $\mathrm{R}_{2}=\mathrm{R}_{3}=\mathrm{H}$<smiles>O=C1CC(c2ccc(O)c(O)c2)Oc2cc(O)cc(O)c21</smiles>

69<smiles>COc1ccc(-c2coc3cc(O)cc(O)c3c2=O)c(OC)c1OC</smiles>

77

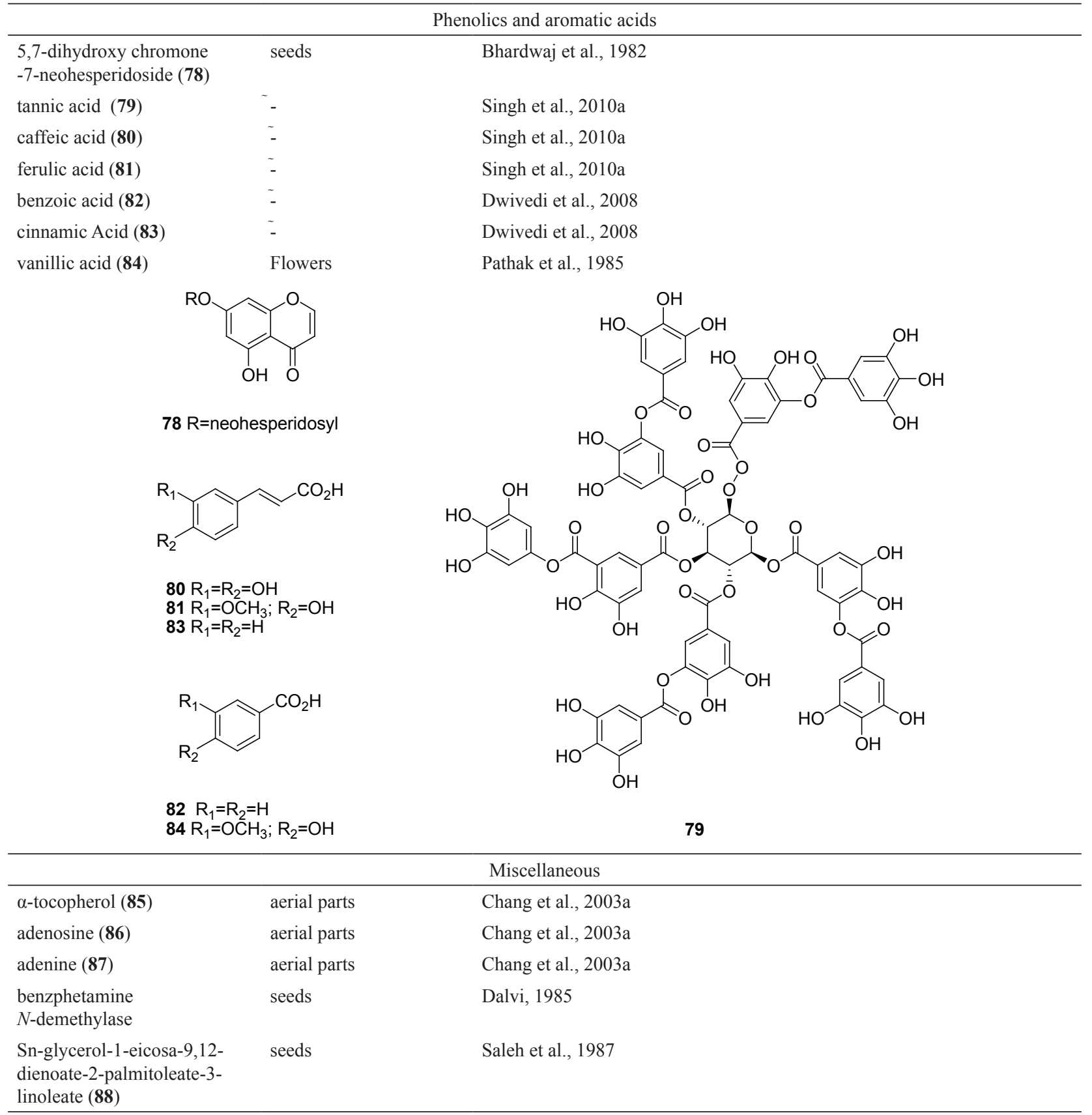


<smiles>Cc1c(C)c2c(c(C)c1O)CC[C@@](C)(CCC[C@H](C)CCC[C@H](C)CCCC(C)C)C2</smiles>

85<smiles>Nc1ncnc2[nH]cnc12</smiles>

87<smiles>Nc1ncnc2c1ncn2C1OC(CO)C(O)C1O</smiles>

86
$\mathrm{CH}_{2} \mathrm{OCOC}_{19} \mathrm{H}_{35}$
$\stackrel{\mathrm{C}}{\mathrm{H} O \mathrm{COC}_{15} \mathrm{H}_{29}}$
$\stackrel{\mathrm{I}}{\mathrm{C}} \mathrm{H}_{2} \mathrm{OCOC}_{17} \mathrm{H}_{31}$

88

Glc: $\beta$-D-glucopyranosyl; Rha: $\alpha$-L-rhamnopyranosyl; Rut: rutinosyl; neohesperidosyl: 2-O-(6-deoxy- $\alpha$-L-mannopyranosyl)- $\beta$-D-glucopyranosyl]

2012) evaluated the antibacterial activity of the aqueous, acetone, ethanol and chloroform extracts of the leaves, stems and roots of the plant against four strains of bacterial species, namely, E. coli, Klebsiella pneumoniae, Bacillus cereus and S. aureus, and found that stems extract possesses greater inhibitory activity compared to the roots and leaves extracts. They reported that ethanol stem extract showed greatest antibacterial activity against $K$. pneumoniae $(22.86$ $\mathrm{mm})$ followed by acetone extract $(17.35 \mathrm{~mm})$ whereas the highest inhibition zone observed for ethanol extract of root against $B$. cereus was $20.05 \mathrm{~mm}$ and the maximum activity of ethanol leaf extract against $S$. aureus was $19.12 \mathrm{~mm}$. Doss et al. (2012) evaluated the leaf extracts (aqueous and alcoholic) of $A$. mexicana to show significant antibacterial activity against a number of bacterial strains such as Streptococcus agalactiae, Escherichia coli, Staphylococcus aureus and Klebsiella pneumonia exhibiting zone of inhibition ranging from 9.0 to $15.0 \mathrm{~mm}$ and $\mathrm{MIC}$ values between 0.225 to $2.00 \mathrm{mg} / \mathrm{mL}$ (Doss et al., 2012). Osho \& Afetunji (2010) investigated in vitro antimicrobial study with essential oil of the plant against some common bacterial and fungal pathogenic microbes and found promising results (Osho \& Afetunji, 2010). The alkaloid, $N$-demethyloxysanguinarine (33), isolated from chloroform extract of $A$. mexicana has been found to show antibacterial activity against $K$. pneumonia, $S$. aureus, E. coli and $P$. aeroginosa with MIC value ranges from 1.5625 to $3.1250 \mathrm{mg} / \mathrm{mL}$ (Bhattacharjee et al., 2010). Rahman et al. (2011) reported that acetone, ethyl acetate and petroleum ether extracts of leaf and stem of A. mexicana exhibit efficiency to inhibit water borne pathogens such as E. coli, Shigella sp., Staphylococcus sp. and Salmonella sp. Petroleum ether extract of both leaf and stem shows maximum activity whereas ethyl acetate shows moderate activity but acetone extract remains inactive.

The alkaloids, dehydrocorydalmine (4) and oxyberberine (32), isolated from $A$. mexicana, were found to exhibit antifungal activities against some fungal strains such as Helminthosporium sp., Curvularia sp., Alternaria cajani, Bipolaris sp. and Fusarium udum (Singh et al., 2009a). Dehydrocorydalmine (4) was found to inhibit spore germination of all the fungal species studied. The spores of Helminthosporium sp. and Curvularia sp. did not germinate at all at 5000 ppm, while Curvularia sp. was found to be highly sensitive at $4000 \mathrm{ppm}$. Alternaria cajani, Bipolaris sp. and Fusarium udum were slightly resistant to this compound as they showed $11.74 \%, 10.15 \%$ and $5.74 \%$ germination, respectively, even at $5000 \mathrm{ppm}$. The other alkaloid, oxyberberine (32) inhibited 100\% spore germination of Bipolaris sp. and Curvularia sp. at $5000 \mathrm{ppm}$. The germination of all the tested fungi was greatly inhibited at 1000 to $4000 \mathrm{ppm}$. A. cajani, Helminthosporium sp. and F. udum were slightly resistant at $5000 \mathrm{ppm}$ (Singh et al., 2009a). A similar study was also carried out by the same group (Singh et al., 2010c) with a mixture of quaternary alkaloids and some phenolic acids (tannic acid 79, caffeic acid $\mathbf{8 0}$ and ferulic acid 81) of the plant. The experimental results also supported significant antifungal potentials of the test compounds.

\section{Anti-HIV activity}

The benzo[c]phenanthridine alkaloid, $( \pm)$-6-acetonyl dihydrochelerythrine (38) isolated from the methanolic extract of air-dried whole plants of $A$. mexicana was found to exhibit potent anti-HIV activity in H9 lymphocyte assay with EC50 value of $1.77 \mu \mathrm{g} /$ $\mathrm{mL}$ (Therapeutic Index: 14.6) (Chang et al., 2003b). 


\section{Anti-inflammatory activity}

The ethanolic extract of leaves of A. mexicana is reported to have significant anti-inflammatory and analgesic activity at a dose of $200 \mathrm{mg} / \mathrm{kg}$ in mice (Sharma et al., 2010). It is also reported that leaf extract of $A$. mexicana is able to show significant anti-inflammatory activity in rats; the investigators (Sukumar et al., 1984) are in opinion that the chemical constituents of the leaf extract such as isorhamnetin-3-O- $\beta$-D-glucopyanoside (70), $\beta$-amyrin (47), cysteine (66) and phenylalanine (67) might be responsible for such activity.

\section{Wound healing activity}

Ghosh and his group (2005) studied in vivo wound healing activity of the extract and the latex of A. mexicana on excision wound healing model the results demonstrated significant wound healing activity of the test extracts that is comparable with the established drug, nitrofurazone; the tensile strength of the extract treated group was found to be higher than the latex treated group of animals on $12^{\text {th }}$ post wounding day (Ghosh et al., 2005). Significant wound healing activity of petroleum ether and butanol fractions of ethanol extract of $A$. mexicana, containing some sterols, alkaloids, proteins and carbohydrates, was also reported in albino rat model by Patil and his group (2001). Dash \& Murthy (2011) investigated wound healing activity using excision, incision and dead space wound models in Wistar albino rats with different extracts of $A$. mexicana leaves. The results revealed that the treatment with methanol extract of leaves of A. mexicana accelerated wound healing agent in rats.

\section{Anti-stress and antiallergic activity}

Both the polar extracts (i.e. aqueous and methanolic) of $A$. mexicana stems were evaluated to exert antiallergic as well as antistress efficacy in asthma developed by milk-induced leucocytosis and milkinduced eosinophilia at a dose of $50 \mathrm{mg} / \mathrm{kg}$ i.p. in albino mice model; both of the test extracts showed significant $(p<0.05)$ decrease in leucocytes and eosinophils in vivo (Bhalke \& Gosavi, 2009).

\section{Vasoconstrictor and vasorelaxant effects}

Paez-Sanchez and his group (2006) evaluated the vascular effects of methanolic extract of the aerial parts $A$. mexicana in rat aortic rings; the test extract was found to produce relaxation from contraction induced by noprepinephrine in a concentration-dependent manner. The overall experimental results demonstrated that the plant extract is able to induce a direct and dual specific effect upon the vascular smooth muscle, mediated, at least in part, by adrenergic receptors.

\section{Anti-fertility activity}

Three isoquinoline alkaloids, dihydropalmatine hydroxide (44), berberine (2) and protopine (9), isolated from the seeds of Argemone mexicana were evaluated to have inhibitory activity against spermatogenesis in dogs at the stage XII of late spermatids on administration at a dose of $30 \mathrm{mg} / \mathrm{kg}$ for 70 days; the numbers of spermatids were found to decrease by $46.5,58.0$ and $97.7 \%$ with compounds 44, 2 and 9, respectively (Gupta et al., 1990). In addition, the total numbers of mature Leydig cells were also decreased by compounds $\mathbf{2}$ and $\mathbf{9}$. The relative antispermatogenic activity was reported to be: $\mathbf{9}>\mathbf{2}>\mathbf{4 4}$.

\section{Cytotoxic activity}

Methanolic extract of $A$. mexicana leaves was found to exhibit cytotoxic activity against healthy mouse fibroblasts (NIH3T3) and three human cancer-cell lines (AGS, HT-29 and MDA-MB-435S) using the MTT [3-(4,5dimethylthiazole-2-yl)-2,5-diphenyltetrazolium bromide] assay as reported by Uddin and his group (2011). The result showed that the extract is much active against MDAMB-435S cancer cell line (IC50 $1.82 \mathrm{mg} / \mathrm{mL}$ ). Chang and his group (2003a) isolated a number of alkaloids from $A$. mexicana and evaluated cytotoxic activity of some of the isolated alkaloids viz. $N$-demethyloxysanguinarine (33), pancorine (34), (+)-argenaxine (27), (+)-higenamine (28), (+)-reticuline (8), angoline (41) and chelerythrine (22) to human nasopharyngeal carcinoma (HONE-1) and human gastric cancer (NUGC) cell lines. Chelerythrine (22) was found to be the most active among the series against NUGC cell lines, whereas (+)-argenaxine (27) showed only a moderate activity. On the other hand, angoline (41) inhibited both HONE-1 and NUGC cancer cell lines (Chang et al., 2003a).

\section{Nematicidal activity}

It was reported that the seed oil of A. mexicana is found to kill Meloidogyne incognita larvae in $17 \mathrm{~min}$ (Das \& Sukul, 1998). The investigators found reduction of nematode infection in terms of root galling, root protein content and nematode population in soil and roots after application of aqueous mixture $(0.2 \%)$ to soil and leaves of Hibiscus esculentus inoculated with $M$. incognita. Nath et al. (1982) investigated nematicidal properties of plant extracts of different parts of $A$. mexicana against $M$. juvanica in experimental test tubes of microplots. They reported that plant extracts are capable of lowering nematode population in the field while larvae were found 
to be immobile in $24 \mathrm{~h}$. Another research group (Shaukat et al., 2002) reported that juvenile mortality of $M$. juvanica is caused by different extracts of $A$. mexicana leaf material, out of which polar solvent extract found to be more effective. Again, seed soaking in aqueous extract of $A$. mexicana is found to reduce penetration of the nematodes juvenile in chick pea, thereby supporting nematicidal efficacy of the plant (Mojumder \& Mishara, 1991).

\section{Antifeedant activity}

It is reported that petroleum ether and aqueous leaf extracts of $A$. mexicana were found to exhibit significant antifeedant activity against second stage larvae of Henosephilachna vigintiocto puncata Fabricius (Rao et al., 1990).

\section{Lousicidal activity}

Kumar and his group (2002) investigated lousicidal efficacy of aqueous leaf extract of $A$. mexicana by conducting mortality and repellency tests on tropicalis peters and found lousicidal activity with $73 \%$ mortality.

\section{Mollucicidal activity}

Two alkaloids, protopine (9) and sanguinarine (23), isolated from the plant are found to exhibit mollucicidal activity by decreasing significantly in the levels of protein, free amino acid, DNA and RNA in the nervous tissue of Lymnaea acuminata and also to cause a significant reduction in phospholipids levels and a simultaneous increase in the rate of lipid peroxidation in the nervous tissue of treated snails (Singh \& Singh, 1999).

\section{Effect on ileum organ}

Capasso and his group (1997) studied the effect of the methanolic extract, its partially purified fraction, and the isolated pure compounds such as protopine (9) and allocryptopine (10) from $A$. mexicana on the morphine withdrawal effect in guinea pig isolated ileum; all the tested materials were observed to reduce the effect significantly and in a concentrationdependent manner, thereby suggesting the possible application of isoquinoline alkaloids as potential agents in the treatment of drug abuse. Further investigation in this direction also indicated that that $\mathrm{CHCl}_{3} / \mathrm{MeOH}$ and $\mathrm{MeOH}$ extracts reduced the contractions of isolated guinea-pig ileum in a dose-dependent manner (Piacente et al., 1998); the effects were attributed to the active compounds identified as protopine (9), allocryptopine (10) and berberine (2).

\section{Fungitoxic activity}

A. mexicana seed extract is found to be fungitoxic against a number of fungal strains (Shah et al., 1992). The latex of the plant was found to exhibit toxicity against Trichophytan mentagrophytes (Asthana et al., 1989). The leaf extract of $A$. mexicana is found to exhibit significant fungitoxic activity against few fruit pathogens like Alternaria alternata, Dreschlera halodes, and Helminthosporium speciferum (Srivastava \& Srivastava, 1998), and also against Curvularia tuberculata (Upadhyay \& Rai, 1990), responsible for die-back diseases.

\section{Antihelmintic activity}

The aqueous plant extracts of $A$. mexicana find useful as significant antihelmintic against Indian earthworm Pheritima posthuma (Jaliwala et al., 2011). Majeed et al. (2011) also investigated antihelmintic activity of alcohol and aqueous extracts of leaves against P. posthuma and Ascardia galli in a dose dependent manner $(6.25,12.5,25,50,100 \mathrm{mg} / \mathrm{mL})$ and found that both the extracts show significant antihelmintic activity at a concentration of $100 \mathrm{mg} / \mathrm{mL}$.

\section{Larvicidal activity}

Acetone fraction of the petroleum ether extract of seeds from A. mexicana exhibited larvicidal and growth inhibiting activity against the $2^{\text {nd }}$ instar larvae of Aedes aegypti at concentrations from 25 to $200 \mathrm{ppm}$ having IC50 values of $13.58 \mathrm{ppm}$ and $17.43 \mathrm{ppm}$ at field condition and laboratory condition, respectively (Sakthivadivel \& Thilagavathy, 2003). Willcox et al. (2007) also reported significant larvicidal activity of acetone fraction of petroleum ether extract of $A$. mexicana seeds against $2^{\text {nd }}$ instar larvae of $A$. aegypti. The leaf extract (in petroleum ether) of the plant also exhibits high larvicidal potential with LC50 value of $48.89 \mathrm{ppm}$ against $3^{\text {rd }}-4^{\text {th }}$ instar larvae of Culex quinquefasciatus (Sakthivadivel et al., 2012). A synergistic action of this plant was also reported in their findings; larvicidal potential of leaf extract of $A$. mexicana increases (LC50 value of $28.60 \mathrm{ppm}$ ) when mixed $(1: 1)$ with that of Clausena dentate.

\section{Antioxidant activity}

Perumal et al. (2010) reported that ethanol extract of $A$. mexicana roots possesses antioxidant activity; at a dose of $100 \mu \mathrm{g} / \mathrm{mL}$ concentration, the extract showed high scavenging activity against DPPH (85.17\%), ABTS (75.27\%) and $\mathrm{H}_{2} \mathrm{O}_{2}(84.25 \%)$ radicals. Different extracts of $A$. mexicana leaves were also reported to exhibit superoxide anion scavenging 
activity by Nitro blue tetrazolium assay with maximum percentage of free radical scavenging at a dosage of 200 $\mu \mathrm{g} / \mathrm{mL}$; acetone extract being the most active showing IC50 value double to that of L-ascorbic acid (Bhardwaj et al., 2011).

\section{Anticancer activity}

The ethanol extract of A. mexicana was reported to exhibit inhibitory activity against human cancer cell lines such as HeLa-B75 (48\%), HL-60 (20.15\%) and PN-15 (58.11\%) (Gacche et al., 2011). Gali et al. (2011) also reported anticancer activity of methanolic extract of A. mexicana leaves against HeLa and MCF-7 cancer cell lines with IC50 values ranging from 1.35 to $1.2 \mu \mathrm{g} / \mu \mathrm{L}$ based on MTT assay results. The investigators also proved that the nature of this cytotoxic activity is apoptotic rather than necrosis and this activity may be due to the presence of flavonoid constituents in leaf.

\section{Antidiabetic activity}

Aqueous extract of aerial parts of $A$. mexicana at a dose of 200 and $400 \mathrm{mg} / \mathrm{kg}$ body weight was reported to have hypoglycemic efficacy in alloxaninduced diabetic rats; significant reduction in blood glucose levels, plasma urea, creatinine, triacylglyceride, cholesterol values and recovery in body weight compared to diabetic control rats and the standard drug treated rats are found when treated with the aqueous extract at a dose of $400 \mathrm{mg} / \mathrm{kg}$ body weight (Nayak et al., 2011). Rout et al. (2011) also found that the hydro-alcoholic extract of aerial parts of $A$. mexicana reduces fasting blood glucose levels in Streptozotocininduced hyperglycemic Wistar albino rats at a dose of 200 and $400 \mathrm{mg} / \mathrm{kg}$ body weight; experimental results also showed that the extract dosage of $400 \mathrm{mg} / \mathrm{kg}$ body weight has effective hypoglycemic activity in comparison with the standard drug metformin at a dose of $300 \mathrm{mg} / \mathrm{kg}$ body wt. (Rout et al., 2011).

\section{Antihepatotoxic activity}

Das et al. (2009) showed promising antihepatotoxic activity of aqueous extract of $A$. mexicana stem in carbon tetrachloride-induced hepatotoxic male Albino Wistar rats; oral administration of 150 and $250 \mathrm{mg} / \mathrm{kg}$ body weight of the extract decreased serum asparate transaminase, alanine aminotransferase and alkaline phosphatase levels. Another research group (Sourabie et al., 2012) also investigated the anti-icterus activity of crude leaf powder of the plant against CCl4-induced hepatotoxicity in Wistar rats; the investigators observed significant increase in the levels of ASAT/GOT (aspartate aminotransferase), ALAT/GPT (alanine aminotransferase) and ALP (alkaline phosphate) while decrease in total bilirubin (TBIL) and direct bilirubin (DBIL) level tested at different doses of 125, 250 and 500 $\mathrm{mg} / \mathrm{kg}$ b.w.

\section{Miscellaneous activities}

The Department of Traditional Medicine in Mali has recognized $A$. mexicana as a standardized phytomedicine for home-based management of malaria (Willcox, 2011; Schrader et al., 2012). Aqueous extract of the aerial parts of the plant was found to exhibit anti-parasite activity against the chloroquineresistant K1 strain of Plasmodium falciparum with an IC50 value $5.89 \mu \mathrm{g} / \mathrm{mL}$; in a randomized, controlled clinical trial, $89 \%$ of patients recovered clinically (95\% with artemisinin based combination therapy), although parasite clearance was only achieved in $9 \%$ of patients (Schrader et al., 2012). No deterioration of severe malaria in patients $>5$ years and $1.9 \%$ deterioration in children $\leq 5$ years were observed in the clinical trials (Willcox et al., 2011). As far as phytochemical constituents are concerned, A. mexicana contains the alkaloids berberine (2), protopine (9) and allocryptopine (10); although these compounds showed in vitro antimalarial activity (IC50 of protopine against the W2-strain $0.91 \mu \mathrm{M}$ ) (Avello Simoes Pires, 2009), berberine is purely absorbed, and the aqueous decoction of the plant was not active against Plasmodium berghei in the mouse model (Willcox et al., 2011; Schrader et al., 2012).

Recently, Amartha \& Chaudhari (2011) reported on neuropharmacological applications of $A$. mexicana; the ethyl acetate and methanol extract of the whole plant of $A$. mexicana exhibited analgesic, locomotor and muscle relaxant activity in Wistar albino mice at an oral dosage of 100, 200 and $400 \mathrm{mg} /$ $\mathrm{kg}$ b.w. Both extracts showed significant activities but methanol extract at a dosage of $200 \mathrm{mg} / \mathrm{kg}$ body weight was found to be more potent for central nervous system activities such as analgesic, anxiolytic and sedative effects (Amartha \& Chaudhari, 2011). In addition, acetone leaf extract of the plant showed significant anti-termitic activity against the Formosan subterranean termite pest, Coptotermes formosanus Shiraki, in a dose-dependent manner; after $48 \mathrm{~h}$ of exposure, the plant extract exhibited LD50 and LD90 values of 253 and $1511 \mathrm{ppm}$, respectively (Elango et al., 2012). Table 2 offers a closer look at the bioactive chemical constituents of $A$. mexicana.

\section{Toxicity and safety evaluation of $A$. mexicana}

Few works on the toxicity and safety evaluation of A. mexicana are reported. Ibrahim \& Ibrahim (2009) showed that the plant extract exhibits acute toxicity 
Table 2. A quick look at the bioactive compounds from A. mexicana.

\begin{tabular}{|c|c|c|}
\hline Compound & Biological activity & Reference \\
\hline berberine (2) & $\begin{array}{l}\text { Anti-fertility activity } \\
\text { Effect on ileum contraction in guinea pig } \\
\text { Antimalarial activity }\end{array}$ & $\begin{array}{l}\text { Gupta et al., } 1990 \\
\text { Piacente et al., } 1998 \\
\text { Avello Simoes Pires, } 2009\end{array}$ \\
\hline dehydrocorydalmine (4) & Antifungal activity & Singh et al., 2009a \\
\hline$(+)$-reticuline $(\mathbf{8})$ & Cytotoxic activity & Chang et al., 2003a \\
\hline protopine (9) & $\begin{array}{l}\text { Anti-fertility activity } \\
\text { Effect on ileum in guinea pig } \\
\text { Mollucicidal activity } \\
\text { Antimalarial activity }\end{array}$ & $\begin{array}{l}\text { Gupta et al., } 1990 \\
\text { Capasso et al., 1997; Piacente et al., } 1998 \\
\text { Singh \& Singh, } 1999 \\
\text { Avello Simoes Pires, } 2009\end{array}$ \\
\hline allocryptopine (10) & $\begin{array}{l}\text { Effect on ileum in guinea pig } \\
\text { Antimalarial activity }\end{array}$ & $\begin{array}{l}\text { Capasso et al., 1997; Piacente et al., } 1998 \\
\text { Avello Simoes Pires, } 2009\end{array}$ \\
\hline chelerythrine (22) & Cytotoxic activity & Chang et al., 2003a \\
\hline sanguinarine (23) & Mollucicidal activity & Singh \& Singh, 1999 \\
\hline$(+)$-argenaxine $(27)$ & Cytotoxic activity & Chang et al., 2003a \\
\hline (+)-higenamine (28) & Cytotoxic activity & Chang et al., 2003a \\
\hline oxyberberine (32) & Antifungal activity & Singh et al., 2009a \\
\hline N-demethyloxysanguinarine (33) & Cytotoxic activity & Chang et al., 2003a \\
\hline pancorine (34) & Cytotoxic activity & Chang et al., 2003a \\
\hline$( \pm)$-6-acetonyl dihydrochelerythrine (38) & Anti-HIV activity & Chang et al., 2003b \\
\hline angoline (41) & Cytotoxic activity & Chang et al., 2003a \\
\hline dihydropalmatine hydroxide (44) & Anti-fertility activity & Gupta et al., 1990 \\
\hline$\beta$-amyrin (47) & Anti-inflammatory \& analgesic activity & Sukumar et al., 1984 \\
\hline cysteine (66) & Anti-inflammatory \& analgesic activity & Sukumar et al., 1984 \\
\hline phenylalanine (67) & Anti-inflammatory \& analgesic activity & Sukumar et al., 1984 \\
\hline isorhamnetin-3-O- $\beta$-D-glucopyanoside (70) & Anti-inflammatory \& analgesic activity & Sukumar et al., 1984 \\
\hline
\end{tabular}

in mice with LD50 value of $400 \mathrm{mg} / \mathrm{kg}$ body weight when administered intraperitoneally in the subjects having weight of $18-25 \mathrm{~g}$ and averagely aged between 4-6 weeks. Seed oil of the plant is also reported to show toxic effects in experimental animals, and such toxicity is supposed primarily due to sanguinarine (23). The alkaloid $\mathbf{2 3}$ is reported to be 2.5 times more toxic than its reduced product, dihydrosanguinarine (39), and both of them are interconvertable by simple oxidation and reduction process (Verma et al., 2001). It is also reported that alkaloid $\mathbf{2 3}$ is the causative component of glaucoma and epidemic dropsy, a disease resulting in neuroparalysis and death of several people (Verma et al., 2001). The mechanism of toxicity of Argemone oil is still not cleared but four different postulations have been described so far to explain the toxicity of sanguinarine - inhibition of $\mathrm{Na}^{+} / \mathrm{K}^{+}$ATPase, cell membrane damage by reactive oxygen species and lipid peroxidation, inhibition of DNA polymerase activity, and accumulation of pyruvate due to increased glycogenolysis (Verma et al., 2001). It is believed that sanguinarine present in Argemone oil is toxic and interferes with the oxidation of pyruvic acid which will accumulate causing dilation of capillaries and small arterioles (Husain et al., 1999). Sanguinarine (23) is reported to have hepatotoxic potential in rats (Dalvi, 1985), because a single i.p. dose $(10 \mathrm{mg} / \mathrm{kg})$ of the compound not only increased the activity of SGPT and SGOT substantially but also caused a significant loss of microsomal cytochrome P-450 and benzphetamine $\mathrm{N}$-demethylase activity. Furthermore, the treated rats exhibited considerable loss of body and liver weight, peritoneal edema and slightly enlarged livers with fibrinous material. Microscopic examination of the liver tissue showed progressive cellular degeneration and necrosis, thereby, establishing that the test compound 23 is a potential hepatotoxic alkaloid (Dalvi, 1985). A detailed study on the metabolism of sanguinarine characterizing the oxidative metabolites produced by human CYP1A1 and CYP1A2 and rat liver microsomes was recently reported by Deroussenta et al. (2010).

Since consumption of mustard oil adulterated with Argemone oil leads to a clinical condition, commonly referred to as "Epidemic dropsy" (Sood et al., 1985; Deroussenta et al., 2010), the in vivo clastogenic and DNA damaging potential of Argemone oil was investigated by Ansari and his group (2004) in mice. In their investigation, Swiss albino mice were 
intraperitoneally administered $0.5,1.0,2.0$ and 4.0 $\mathrm{mL} / \mathrm{kg}$ body weight of the oil to analyze chromosome aberrations and micronucleus test, while $0.25,0.5,1.0$ and $2.0 \mathrm{~mL} / \mathrm{kg}$ body weight were given for alkaline comet assay. The frequencies of chromosomal aberrations and micronucleated erythrocytes formation in mouse bone marrow cells increased in a dose-dependent manner following the oil treatment. However, significant induction in chromosomal aberrations $(83 \%)$ and micronucleated erythrocytes formation (261\%) were observed at a minimum dose of $1.0 \mathrm{~mL} / \mathrm{kg}$. The results of comet assay revealed DNA damage in blood, bone marrow and liver cells following Argemone oil treatment. These results clearly suggest that single exposure of test oil even at low doses can produce genotoxic effects in mice (Ansari et al., 2004). The same research group (Ansari et al., 2005) also studied the in vivo DNA damaging potential of sanguinarine $\mathbf{2 3}$ in blood and bone marrow cells of mice using alkaline comet assay. Swiss albino male mice were given single intraperitoneal administration of $1.35,2.70,5.40$, 10.80 and $21.60 \mathrm{mg}$ sanguinarine alkaloid/kg body weight, while controls were treated with saline in the same manner. The results revealed a dose dependent increase in DNA damage in blood and bone marrow cells following $24 \mathrm{~h}$ treatment of sanguinarine alkaloid 23. All the three parameters of comet assay including olive tail moment (OTM), tail length and tail DNA showed significant $(p<0.05)$ increases in blood and bone marrow cells at respective doses of 10.80 and $5.40 \mathrm{mg}$ alkaloid $/ \mathrm{kg}$ body weight. These results indicate that single exposure of the test compound causes DNA damage in blood and bone marrow cells of mice, which could be responsible for the genotoxicity of Argemone oil (Ansari et al., 2005). Upreti et al. (1989) showed that membrane destruction may be a possible mode of action for damaging liver, lungs, heart and kidneys of rats due to Argemone oil toxicity in rats. This oil, one of the adulterants encountered in edible oil, is also reported to be responsible for gall bladder cancer in Swiss albino rat-model (Mishra et. al, 2012).

\section{Discussions and critical comments}

The present article deals with an up-to-date review on the chemistry and pharmacology of Argemone mexicana, a useful medicinal plant finding applications in indigenous systems of medicine. The plant species belongs to the family Papaveraceae, informally known as the poppy family; plants under this family are an ethnopharmacologically important family of 44 genera and approximately 760 species of flowering plants. Argemone mexicana $\mathrm{L}$. is used in different parts of the world for the treatment of several diseases including tumors, warts, skin diseases, inflammations, rheumatism, jaundice, leprosy, microbial infections, and malaria. Beyond alkaloids, the plant species is the source of a diverse kind of other chemical constituents that include terpenoids, steroids, carbohydrates, long-chain aliphatic alcohols and carboxylic acids, amino acids, flavonoids and other phenolics. Besides pharmaceutical efficacies, certain parts of the plant also show toxic effects as well; toxicity and safety evaluation of using this plant and its chemical constituents are also dealt in this review. Hence, an upto-date information on the chemical and pharmacological knowledge on this plant may be helpful to guide researchers anticipating to undertake further investigations on this plant. Pharmacological and clinical studies of different chemical constituents of $A$. mexicana are found to be very promising, which calls for more-systematic research of this medicinal plant and its active principles; more in-depth and extensive studies in all relevant aspects are still warranted. We do anticipate that the present overview would boost the on-going development in this direction.

\section{Acknowledgements}

The authors are thankful to the Chemistry Department, Visva-Bharati University for providing infrastructural facilities. Financial support from the UGC, New Delhi is also deeply acknowledged.

\section{Authors' contributions}

The concept, design, and arrangement of the present review article were contributed by GB; he also analyzed all the data, supervised the process of drafting and contributed in finalizing the article through critical reading of the draft manuscript. $\mathrm{DG}$ and $\mathrm{RR}$ both contributed equally in collecting exhaustive searching on the databases, summarizing the data and preparing a draft. All the authors have read the final manuscript and approved the submission

\section{References}

Abubacker MN, Ramanathan R 2012. Antibacterial activities of Argemone mexicana L. (Papaveraceae) leaf extract on pathogenic bacterial strains. Drug Invention Today 4: 385-387.

Agra MF, Baracho GS, Nurit K, Basilio IJLD, Coelho VPM 2007. Medicinal and poisonous diversity of the flora of "Cariri Paraibano", Brazil. J Ethnopharmacol 111: 383-395.

Agra MF, Silva KN, Basílio IJLD, de Freitas PF, BarbosaFilho JM 2008. Survey of medicinal plants used in the region Northeast of Brazil. Rev Bras Farmacogn 18: 472-508.

Alagesaboopathi C, Kalaiselvi N 2012. Antimicrobial activities of the root, stem and leaf extracts of 
Argemone mexicana L. Int J Biosci 2: 61-68.

Albuquerque UP, Monteiro JM, Ramosa MA, Amorim ELC 2007. Medicinal and magic plants from a public market in northeastern Brazil. J Ethnopharmacol 110: 76-91.

Amartha S, Chaudhari S 2011. Neuropharmacological study of Argemone mexicana Linn. J App Pharm Sci 1: 121126.

Ambasta SP 1986. The useful plants of India. New Delhi: PID, CSIR, p. 51.

Ansari KM, Chauhan LKS, Dhawan A, Khanna SK, Das M 2004. Unequivocal evidence of genotoxic potential of argemone oil in mice. Int J Cancer 112: 890-895.

Ansari KM, Dhawan A, Khanna SK, Das M 2005. In vivo DNA damaging potential of sanguinarine alkaloid, isolated from argemone oil, using alkaline Comet assay in mice. Food Chem Toxicol 43: 147-153.

Anthal S, Roy R, Gupta VK, Rajnikant, Brahmachari G, Jash SK, Mandal LC 2012. Crystal structure of 3-( $\beta-\mathrm{D}-$ glucopyranosyloxy)-5,7-dihydroxy-2-(4-hydroxy-3methoxyphenyl)-4H-1-benzopyran-4-one trihydrate. X-ray Structure Analysis Online 28: 15-16.

Asthana A, Mall HV, Dixit K, Gupta S 1989. Fungitoxic properties of latex of plants with special reference to that of Corton bonplandianum Boill. Int J Crude Drug Res 27: 25-28.

Avello Simoes Pires C 2009. Investigation of antiplasmodial compounds from various plant extracts Thèse de doctorat. Univ. Genève. no. Sc., 4129.

Badami RC, Gunstone FD 1962. Vegetable oils. X. Examination of component acids of Argemone mexicana seed oil by reversed-phase chromatography. J Sci Food Agric 13: 255-257.

Bhalke, RD, Gosavi, SA 2009. Anti-stress and antiallergic effect of Argemone mexicana stems in asthma. Arch Pharm Sci Res 1: 127-129.

Bhardwaj DK, Bisht MS, Jain RK, Munyal A 1982. Phenolics from the seeds of Argemone mexicana. Phytochemistry 21: 2154-2156.

Bhardwaj M, Duhan JS, Kumar A, Surekha 2012. Antimicrobial potential of Argemone mexicana: An in vitro study. Asian J Microbiol Biotechnol Environ Sci 14: 353-357.

Bhardwaj M, Surekha, Duhan JS 2011. Free radicalscavenging and antimutagenic potential of acetone, chloroform and methanol extracts of leaf of Argemone mexicana, Int J Pharm Biosci 2: 455-464.

Bhattacharjee I, Chattarjee SK, Chandra G 2010. Isolation and identification of antibacterial components in seed extracts of Argemone mexicana L. (Papaveraceae). Asian Pac J Trop Med 3: 547-551.

Bhattacharjee I, Chattarjee SK, Chattarjee K, Chandra G 2006. Antibacterial potentiality of Argemone mexicana solvent extracts against some pathogenic bacteria. Mem I Oswaldo Cruz 101: 645-648.
Bieski IGC, Santos FR, de Oliveira RM, Espinosa MM, Macedo M, Albuquerque UP, de Oliveira Martins DT 2012. Ethnopharmacology of medicinal plants of the pantanal region (Mato Grosso, Brazil). Evi-Based Compl Alt 2012: 1-36 doi:10.1155/2012/272749.

Bose BC, Vijayvargiya R, Saifi AQ, Sharma SK 1963. Chemical and pharmacological studies on Argemone mexicana. J Pharm Sci 52: 1172-1175.

Brahmachari G, Roy R, Mandal LC, Ghosh PP, Gorai D 2010. A new long-chain alkanediol from the flowers of Argemone mexicana. J Chem Res 11: 656-657.

Capasso A, Piacente S, Pizza C, Tommasi ND, Jativa C, Sorrentino L 1997. Isoquinoline alkaloids from Argemone mexicana reduce morphine withdrawal in guinea pig isolated ileum. Planta Med 63: 326-328.

Chang YC, Chang FR, Khalil AT, Hsieh PW, Wu YC 2003a. Cytotoxic benzophenanthridine and benzylisoquinoline alkaloids from Argemone mexicana. Z Naturforsch $58 \mathrm{c}$ : 521-526.

Chang YC, Hsieh PW, Chang FR, Wu RR, Liaw CC, Lee KH, $\mathrm{Wu}$ YC 2003b. Two new protopines argemexicaines $\mathrm{A}$ and $\mathrm{B}$ and the anti-HIV alkaloid 6-acetonyl dihydrochelerythrine from formasan Argemone mexicana. Planta Med 69: 148-152.

Chopra RN, Nayar SL, Chopra IC 1956. Glossary of Indian medicinal plants. New Delhi: NISCOM, CSIR, p. 23.

Dalvi RR 1985. Sanguinarine: its potential, as a liver toxic alkaloid present in the seeds of Argemone mexicana. Experientia 41: 77-78.

Das PK, Sethi R, Panda P, Pani SR 2009. Hepatoprotective activity of plant Argemone mexicana (Linn) against carbon tetrachloride (CC14) induced hepatotoxicity in rats. Int J Pharm Res Dev 8: 1-20.

Das S, Sukul NC 1998. Nematicidal effect of the oil from the seeds of Argemone mexicana. Env Ecol 6: 194-197.

Dash GK, Murthy PN 2011. Evaluation of Argemone mexicana Linn. leaves for wound healing activity, J Nat Prod Plant Resour 1: 46-56.

Deroussenta A, Ré M, Hoellinger H, Cresteil T 2010. Metabolism of sanguinarine in human and in rat: Characterization of oxidative metabolites produced by human CYP1A1 and CYP1A2 and rat liver microsomes using liquid chromatography-tandem mass spectrometry. $J$ Pharmaceut Biomed 52: 391-397.

Dinda B, Banerjee J 1987. Aliphatic compounds from Argemone mexicana. Chem Ind (London), 12: 419420.

Doss A, Mubaracki HM, Vijayasanthi M, Venkataswamy R 2012. In-vitro antibacterial activity of certain wild medicinal plants against bovine mastitis isolated contagious pathogens. Asian J Pharmaceut Clin Res 5: 90-93.

Dwivedi S, Dwivedi A, Kapadia R 2008. Argemone mexicana Linn. (Ghamoya): A weed having great therapeutic values in folk remedies. Pharm Rev 6. http://www. pharmainfo.net/reviews/argemone-mexicana-linn- 
ghamoya-weed-having-great-therapeutic-valuesfolk-remedies, accessed 1 Aug 2012.

Elango G, Abdul Rahuman A, Kamaraj C, Bagavan A, Abduz Zahir A, Santhoshkumar T, Marimuthu S, Velayutham K, Jayaseelan C, Vishnu Kirthi A, Rajakumar G 2012. Efficacy of medicinal plant extracts against Formosan subterranean termite, Coptotermes formosanus. Ind Crop Prod 36: 524-530.

Fletcher MT, Takken G, Blaney BJ, Alberts V 1993. Isoquinoline alkaloids and keto-fatty acids of Argemone ochroleuca and A. mexicana (mexican poppy) seed. I. An assay method and factors affecting their concentration. Aus $J$ Agric Res 44: 265-275.

Gacche RN, Shaikh RU, Pund MM 2011. In vitro evaluation of anticancer and antimicrobial activity of selected medicinal plants from Ayurveda. Asian J Trad Med 6: $127-133$

Gali K, Ramakrishnan G, Kothai R, Jaykar B 2011. In-vitro anti-cancer activity of methanolic extract of leaves of Argemone mexicana Linn. Int J PharmTech Res 3: 1329-1333.

Ghosh T, Dash GK, Bose A, Panda BR 2005. Wound healing properties of Argemone mexicana. Indian J Nat Prod 20: 3-6.

Gunstone FD, Holliday JA, Scrimgeour CM 1977. Fatty acids, part 51. The long-chain oxo acids (argemonic acid) in Argemone mexicana seed oil. Chem Phys Lipids 20: 331-335.

Gupta RS, Dixit VP, Dobhal MP 1990. Antifertility studies of isoquinoline alkaloids with special emphasis on structure activity relationship. Fitoterapia 61: 67-71.

Haisova K, Slavik J 1975. On the minor alkaloids from Argemone mexicana L. Collect Czech Chem Commun 40: 1576-1578.

Harborne JB, Williams CA 1983. Flavonoids in the seeds of Argemone mexicana: a reappraisal. Phytochemistry 22: 1520-1521.

Husain S, Narsimha R, Roa RN 1999. Separation, identification and determination of sanguinarine in argemone and other adulterated edible oils by reversed-phase highperformance liquid chromatography. $J$ Chromatogr A 863: 123-126.

Hussain SF, Nakkady S, Khan L, Shamma M 1983. Oxyhydrastinine, an isoquinolone alkaloid from the papaveraceae. Phytochemistry 22: 319-320.

Ibrahim HA, Ibrahim H 2009. Phytochemical screening and toxicity evaluation on the leaves of Argemone mexicana Linn. (Papaveraceae). Int Jor App Sci 3: 39-43.

Israilov IA, Yuhusov MS 1986. Alkaloids of four Agremone species. Khim Prir Soedin 2: 204-206.

Ito C, Furukawa H 1990. Antifertility studies of isoquinoline alkaloids with special emphasis of structure activity relationship. Fitoterapia 61: 67-71.

Jain RA, Agarwal RC, Dubey D, Verma R, Jain R 2012.
Evaluation of antibacterial and antioxidant activity of fruits extract of Argemone mexicana Linn. Int $J$ Pharm innov 2: 45-51.

Jaliwala YA, Panda PK, Chourasia N, Bhatt NK, Pandit A, Mohanty PK 2011. In vitro anthelmintic activity of aerial parts of Argemone mexicana Linn. J Pharm Res 4: 3173-3174.

Krishnamurthi M, Ramanathan JP, Seshadri TR, Shankaran PR 1965. Flavonol glycosides of Argemone mexicana flowers. Indian J Chem 3: 270-272.

Kumar S, Singh SK, Baslas RK, Ghildiyal JC, Saxena AK 2002. Lousicidal properties of few aqueous plant extracts. Indian Vet J 79: 1136-1140.

Majeed A, Taju G, Nathiga Nambi KS, Menaka H 2011. Anthelmintic activity of Argemone mexicana leaves extract against Pheretima prosthuma and Ascardia galli. Res J Pharm Biol Chem Sci 2: 773-777.

Makhija IK, Khamar D 2010. Anti-snake venom properties of medicinal plants. Der Pharmacia Lettre 2: 399-411.

Migahid AM 1978. Flora of Saudi Arabia. 2. ed. Saudi Arabia: Riyadh University Press, Riyadh, p. 34.

Mishra V, Mishra M, Ansari KM., Chaudhari BP, Khanna R, Das M 2012. Edible oil adulterants, argemone oil and butter yellow, as aetiological factors for gall bladder cancer. Eur J Cancer 48: 2075-2085.

Minu V, Harsh V, Ravikant T, Paridhi J, Noopur S 2012. Medicinal plants of Chhattisgarh with anti-snake venom property. Int J Curr Pharm Rev Res 3: 1-10.

Mojumder V, Mishara SD 1991. Nematicidal efficacy of some plant products and management of Meloidogyne incognita in pulse crops by soaking seeds in their aqueous extracts. Curr Nematol 2: 27-32.

Nakkady S, Shamma M 1988. Studies on the chemical constituents of Argemone mexicana. Egypt J Pharm Sci 29: 53-61.

Nath R, Khan MN, Kamalwanshi RS, Diwedi RP 1982. Effect of Argemone mexicana on Meloidogyne juvanica in Okra (Abelmaschus esculentus). Indian J Nematol 12: 205-208.

Nayak P, Kar DM, Maharana L 2011. Antidiabetic activity of aerial parts of Argemone mexicana L. in alloxan induced hyperglycaemic rats. Pharmacologyonline 1: 889-903.

Osho A, Afetunji T 2010. Antimicrobial activity of the essential oil of Argemone mexicana Linn. J Med Plant Res 4: 19-22.

Paez-Sanchez E, Fernandez-Saavedra G, Magos GA 2006. Vasoconstrictor and vasorelaxant effects of a methanolic extract from Argemone mexicana Linn (Papaveraceae) in rat aortic rings. Proc West Pharmacol Soc 49: 63-65.

Pandey A, Karanwal V 2011. A study of extract optimization and effect of metal ions on antibacterial properties of Argemone mexicana. Asian J Plant Sci Res 1: 43-48.

Pathak NKR, Biswas M, Seth KK, Dwivedi SPD, Pandey VB 1985. Chemical investigation of Argemone mexicana. Die Pharmazie 40: 202. 
Patil MB, Jalalpure SS, Ali A 2001. Preliminary phytochemical investigation and wound healing activity of the leaves of Argemone mexicana Linn. (Papaveraceae). Indian Drugs 38: 288-293.

Perumal P, Sekar V, Rajesh V, Gandhimathi S, Kumar RS, Nazimudin KHS 2010. In vitro antioxidant activity of Argemone mexicana roots. Int J PharmTech Res 2: 1477-1482.

Piacente S, Capasso A, De Tommasi N, Jativa C, Pizza C, Sorrentino L 1998. Different effects of some isoquinoline alkaloids from Argemone mexicana on electrically induced contractions of isolated Guineapig ileum. Phytother Res 11: 155-157.

Prajapati ND, Purohit SS, Sharma AK, Kumar T 2003. A handbook of medicinal plants. Jodhpur, India: Agrobios, p. 59-60.

Rahman MM, Alam MJ, Sharmin SA, Rahman MM, Rahman A, Alam MF 2009. In vitro antibacterial activity of Argemone mexicana L (Papaveraceae). CMU J Nat Sci 8: 77-84.

Rahman A 1994. Hand book of natural products data in isoquinoline alkaloids. Pakistan: H.E.J. Research institute of chemistry, University of Karachi, p. 23.

Rahman MS, Salehin MF, Jamal AHM, Parvin A, Alam MK 2011. Antibacterial activity of Argemone mexicana $\mathrm{L}$ against water borne microbes. Res $J$ Med Plant 5: 621-626.

Rahman W, Ilyas M 1962. Flower Pigments. Flavonoids from Argemone mexicana L. (Papaveraceae). J Org Chem 27: 153-155.

Rao SM, Chitra KC, Gunesekhar D, Kameswara Rao P 1990. Antifeedant properties of certain plant extracts against second stage larva of Henosephilachna vigintiocta puncata Fabricius. Indian J Entomol 52: 681-685.

Rosas-Pinon Y, Mejia A, Diaz-Ruiz G, Aguilara MI, SanchezNietoc S, Rivero-Cruza JF 2012. Ethnobotanical survey and antibacterial activity of plants used in the altiplane region of Mexico for the treatment of oral cavity infections. J Ethnopharmacol 141: 860-865.

Rout SP, Kar DM and Mandal PK 2011. Hypoglycaemic activity of aerial parts of Argemone mexicana L. in experimental rat models. Int J Pharm Pharmaceut Sci 3: $533-540$

Rukmini C 1975. New, unusual long chain fatty acid (argemonic acid) from Argemone mexicana. J Am Oil Res Soc 52: 171-173.

Sahu MC, Debata NK, Padhy RN 2012. Antibacterial activity of Argemone mexicana L. against multidrug resistant Pseudomonas aeruginosa, isolated from clinical samples. Asian Pac J Trop Biomed: S800-S807.

Sakthivadivel M, Thilagavathy D 2003. Larvicidal and chemosterilant activity of the acetone fraction of petroleum ether extract from Argemone mexicana L. seed. Biores Technol 89: 213-216.

Sakthivadivel M, Eapen A, Dash AP 2012. Evaluation of toxicity of plant extracts against vector of lymphatic filariasis, Culex quinquefasciatus. Indian J Med Res 135: 397-400.

Saleh MA, Rahman FHA, Ibrahim NA, Taha NM 1987. Isolation and structure determination of new nematicidal triglyceride from Argemone mexicana. $J$ Chem Ecol 13: 1361-1370.

Sangwan NK, Malik MS 1998. A long chain alcohol from Argemone mexicana. Phytochemistry 49: 755-756.

Saranya MS, Arun T, Iyappan P 2012. In vitro antibacterial activity and preliminary phytochemical analysis of leaf extracts of Argemone mexicana L. - A medicinal plant. Int J Curr Pharm Res 4: 85-87.

Sarraf S, Tyagi S, Ojha AC, Rawat GS 1994. Phytochemical study of some medicinal plants. Himalayan Chem Pharm Bull 11: 22-24.

Savithramma N, Sulochana Ch, Rao KN 2007. Ethnobotanical survey of plants used to treat asthma in Andhra Pradesh, India. J Ethnopharmacol 113: 54-61.

Schrader FC, Barho M, Steiner I, Ortmann R, Schlitzer M 2012. The antimalarial pipeline - An update. Int J Med Microbiol 302: 165-171.

Shah NH, Khan IM, Azam MF 1992. Seed mycoflora of Cowpea and its control with extract of Argemone mexicana. Bioved 3: 167-168.

Shamma M 1972. The isoquinoline alkaloids, chemistry and pharmacology. Vol 25. Academic Press, New York \& London.

Sharma J, Gairola S, Gaur RD, Painuli RM 2012. The treatment of jaundice with medicinal plants in indigenous communities of the Sub-Himalayan region of Uttarakhand, India. J Ethnopharmacol 143: 262-291.

Sharma S, Sharma MC, Kohli, DV 2010. Pharmacological screening effect of ethanolic and methanolic extract of fruits of medicinally leaves. Dig J Nanomat Biostr 5: 229-232.

Shaukat SS, Siddiqui IA, Khan GH, Zaki MJ 2002. Nematicidal and allelopathic potential of Argemone mexicana, a tropical weed. Plant Soil 245: 239-247.

Singh A, Singh S, Singh S, Singh TD, Singh VP, Pandey VB, Singh, UP 2009a. Fungal spore germination inhibition by alkaloids dehydrocorydalmine and oxyberberine. $J$ Plant Prot Res 49: 287-289.

Singh S, Pandey VB, Singh TD 2012. Alkaloids and flavonoids of Argemone mexicana. Nat Prod Res 26: 16-21.

Singh S, Singh A, Jaiswal J, Singh TD, Singh VP, Pandey VB, Tiwari A, Singh UP 2010a. Antifungal activity of the mixture of quaternary alkaloids isolated from Argemone mexicana against some phytopathogenic fungi. Arch phytopathol Plant Prot 43: 769-774.

Singh S, Singh DK 1999. Effect of mollucicidal components of Abrus precatorius, Argemone mexicana and Nerium indicum on certain biochemical parameters of Lymnaeu acuminate. Phytother Res 13: 210-213.

Singh S, Singh TD, Pandey VB 2011. Constituents of 
Argemone species. J Indian Chem Soc 88: 275-276.

Singh S, Singh TD, Singh VP, Pandey VB 2010b. A new benzylisoquinoline alkaloid from Argemone mexicana. Nat Prod Res 24: 63-67.

Singh S, Singh TD, Singh VP, Pandey VB 2010c. Quaternary alkaloids of Argemone mexicana. Pharm Biol 48: 158-160.

Singh SK, Pandey VD, Singh A, Singh C 2009b. Antibacterial activity of seed extracts of Argemone mexicana L. on some pathogenic bacterial strains. African $J$ Biotechnol 8: 7077-7081.

Sood NN, Sachdev MS, Mohan M, Gupta SK, Sachdev HPS 1985. Epidemic dropsy following transcutaneous absorption of Argemone mexicana oil. T Roy Soc Trop Med Hyg 79: 510-512.

Sourabie TS, Ouedraogo N, Sawadogo WR, Yougbare N, Nikiema JB, Guissou IP, Nacoulma OG 2012. Evaluation of the anti-icterus effect of crude powdered leaf of Argemone mexicana L. (Papaveraceae) against CCl4-induced liver injury in rats. Int J Pharm Sci Res 3: 491-496.

Srivastava A, Srivastava M 1998. Fungitoxic effect of some medicinal plants (on some food pathogens). Phillippine J Sci 127: 181-187.

Sukumar D, Nambi RA, Sulochana N 1984. Studies on the leaves of Agremone mexicana. Fitoterapia 55: 325353.

Tripathi PN, Tripathi M, Pandey VB, Singh D 1999. Alkaloids of Argemone mexicana. Oriental J Chem 15: 185186.

Uddin SJ, Grice D, Tiralongo E 2011. Cytotoxic effects of
Bangladeshi medicinal plant extracts. Evid-Based Comp Alt, Article ID 578092, doi: 10.1093/ecam/ nep111.

Upadhyay S, Rai MK 1990. In vitro sensitivity of Curvularia tuberculata Jain: A casual organism die-back disease of citrous to different plant extracts. Indian Medicine 1: $13-15$.

Upreti KK, Das M, Kumar A, Singh GB, Khanna SK 1989. Biochemical toxicology of argemone oil. IV short-term oral feeding response in rats. Toxicol 58: 285-298.

Verma SK, Dev G, Tyagi AK, Goomber S, Jain GV 2001. Argemone mexicana poisoning: autopsy findings of two cases. Forensic Sci Inter 115: 135-141.

Willcox M 2011. Improved traditional phytomedicines in current use for the clinical treatment of malaria. Planta Med 77: 662-671.

Willcox ML, Graz B, Falquet J 2007. Argemone mexicana decoction for the treatment of uncomplicated falciparum malaria. T Roy Soc Trop Med Hyg 101: 1190-1198.

Willcox ML, Graz B, Falquet J, Diakite C, Giani S, Diallo D 2011. A reverse pharmacology approach for developing an anti-malarial phytomedicine. Malaria J 10: S8. doi:10.1186/1475-2875-10-S1-S8

\section{*Correspondence}

Goutam Brahmachari

Laboratory of Natural Products \& Organic Synthesis, Department of Chemistry, Visva-Bharati University Santiniketan-731235, West Bengal, India goutam.brahmachari@visva-bharati.ac.in 